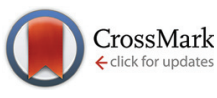

Cite this: Dalton Trans., 2015, 44, 9363

Received 13th March 2015, Accepted 15th April 2015

DOI: $10.1039 / \mathrm{c} 5 \mathrm{dt} 01360 \mathrm{~g}$

www.rsc.org/dalton

\section{Syntheses, structures and theoretical investigations of $\left[\mathrm{Au}_{10} \mathrm{~S}_{2}\left(\mathrm{PPh}_{2}\right)_{2}(\mathrm{dppma2})_{4}{ }^{-}\right.$ (dppma3)] $\left[\mathrm{Au}_{6} \mathrm{~S}_{2}(\mathrm{dppma2})_{2}(\mathrm{dppma3})\right]+$ t}

\author{
Wen Yu, ${ }^{a, b}$ Lukas Guggolz, ${ }^{a}$ Olaf Fuhr, ${ }^{c, d}$ Dieter Fenske ${ }^{\star b, c, d}$ and Stefanie Dehnen ${ }^{a}$
}

The synthesis, crystal structure and theoretical studies of a highnuclear gold(I) complex stabilized by bridging aromatic phosphane ligands are reported. The complex is composed of a neutral $\mathrm{Au}_{10}$ complex unit with a horseshoe-like structure around a neutral $\mathrm{Au}_{6}$ complex unit with a distorted cubane-like structure.

The chemistry of polynuclear gold(I) complexes has attracted increasing attention in the past few decades. With a closedshell electronic configuration of $\mathrm{d}^{10}$, gold(I) ions adopt a linear two-coordinate coordination geometry and tend to form weak

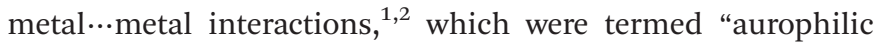
interactions" by Schmidbaur. ${ }^{2,3}$ They are found in a huge number of polynuclear aggregates that possess a wide diversity of configurations and were successfully traced in several early theoretical investigations by extended Hückel quantum chemical calculations. Due to the high stability and the relatively good accessibility of synthetic routes, chalcogenide-based polynuclear gold(I) complexes, especially sulfide- and selenidebridged gold(I) complexes, are among the most popular systems in the gold family. Many polynuclear gold(I) clusters of bridging phosphane ligands, with pyramidal $\left[\mathrm{Au}_{3}\left(\mu_{3}-\mathrm{S}\right)\right]^{+}$units, are linked via metal...metal interactions. Examples include clusters with the formulae $\left[\mathrm{Au}_{5}\left(\mathrm{PPh}_{2}\right)_{3}(\mathrm{dppma2})\right],{ }^{4}\left[\mathrm{Au}_{10} \mathrm{Se}_{4}-\right.$ $\left.(\mathrm{dppm})_{4}\right]^{2+}(\mathrm{dppm}=$ bis(diphenyl-phosphino)methane $){ }^{5}$

\footnotetext{
${ }^{a}$ Fachbereich Chemie and Wissenschaftliches Zentrum für Materialwissenschaften (WZMW), Philipps-Universität Marburg, Hans-Meerweinstraße 4, 35043 Marburg, Germany. E-mail: dehnen@chemie.uni-marburg.de; Fax: +4964212825653; Tel: +4964212825751

${ }^{b}$ Institut für Anorganische Chemie, Karlsruher Institut für Technologie (KIT), Engesserstrasse 15, 76131 Karlsruhe, Germany

${ }^{c}$ Institut für Nanotechnologie (INT) und Karlsruher Nano-Micro-Facility (KNMF), Karlsruher Institut für Technologie (KIT), Hermann-von-Helmholtz-Platz 1, 76344 Eggenstein-Leopoldshafen, Germany

${ }^{d}$ Lehn Institute of Functional Materials (LIFM), Sun Yat-Sen University, 135 Xingang Road West, Guangzhou 510275, China

$\dagger$ This Communication is dedicated to Professor Manfred Scheer on the occasion of his 60th birthday.

\$Electronic supplementary information (ESI) available: Details of syntheses, analyses and quantum chemistry. CCDC 1046523. For ESI and crystallographic data in CIF or other electronic format see DOI: 10.1039/c5dt01360g
}

$\left[\mathrm{Au}_{18} \mathrm{Se}_{8}(\mathrm{dppthph})_{6}\right]^{2+} \quad$ (dppthph $=2,5$-bis(di-phenylphosphino)-thiophene) ${ }^{6}$ and a series of decanuclear compounds recently published by Yam and co-workers, $\left[\mathrm{Au}_{10} \mathrm{~S}_{4}\left\{\left(\mathrm{Ph}_{2} \mathrm{P}\right)_{2^{-}}\right.\right.$ $\left.\left.\mathrm{NC}_{n} \mathrm{H}_{2 n+1}\right\}_{4}\right]^{2+}$ and $\left[\mathrm{Au}_{10} \mathrm{E}_{4}\left\{\left(\mathrm{Ph}_{2} \mathrm{P}\right)_{2} \mathrm{NC}_{6} \mathrm{H}_{4} \mathrm{X}\right\}_{4}\right]^{2+}(n=8,12,14$, $18 ; \mathrm{E}=\mathrm{S}, \mathrm{Se} ; \mathrm{X}=\mathrm{H}, \mathrm{Me}, \mathrm{OMe}, \mathrm{F}, \mathrm{Cl}, \mathrm{Br})^{7,8}$

In this work, we report on further extension of the investigations considering ligands that are based on maleic anhydride. In particular, we used a chlorogold(I) precursor containing the 2,3-bis(diphenylphosphino)maleic anhydride (dppma) ligand, [( $\left.\mathrm{AuCl})_{2}(\mathrm{dppma})\right]$, to form polynuclear gold(I) $\mu_{3}$-sulfido clusters. The dppma ligand is known to assist the stabilization of mononuclear 19-electron complexes by electron delocalization into the low-lying $\pi^{*}$ orbital of the phosphane ligand, ${ }^{9,10}$ which led to the formation of a number of stable 19-electron complexes of $\mathrm{Mn}$ and $\mathrm{Co}$, for example [(dppma)Co $\left.(\mathrm{CO})_{3}\right]$ and $\left[(\mathrm{dppma}) \mathrm{Mn}(\mathrm{CO})_{4}\right]$, in which the odd electron appears to be ligand-centered. ${ }^{10,11}$ This redox-active phosphane ligand seems to be an interesting point also for gold sulfide chemistry, as has been shown in some preliminary studies.

Both the ligand and the respective gold(I) precursor $\left[(\mathrm{AuCl})_{2}(\mathrm{dppma})\right]$ were prepared according to literature methods and treated under inert conditions. ${ }^{4}$ Reaction of the latter with $\mathrm{S}\left(\mathrm{SiMe}_{3}\right)_{2}$ in $\mathrm{CH}_{2} \mathrm{Cl}_{2}$ (with traces of water) yielded a mixture of different complexes, $\left[\mathrm{Au}_{5}\left(\mathrm{PPh}_{2}\right)_{3}(\mathrm{dppma} 2)_{2}\right]^{4}$ and $\left[\mathrm{Au}_{24}\left(\mathrm{PPh}_{2}\right)_{4} \mathrm{~S}_{6}(\mathrm{dppma2})_{8}\right]$, ${ }^{4,12}$ reported recently, and the yet unknown compound $\left[\mathrm{Au}_{10} \mathrm{~S}_{2}\left(\mathrm{PPh}_{2}\right)_{2}(\mathrm{dppma} 2)_{4}(\mathrm{dppma})\right]$. $\left[\mathrm{Au}_{6} \mathrm{~S}_{2}(\mathrm{dppma})_{2}(\mathrm{dppma3})\right]$ (1, Fig. 1), in single crystalline form according to the following reaction scheme:

$$
\begin{aligned}
& {\left[(\mathrm{AuCl})_{2}(\mathrm{dppma})\right]+1.2 \mathrm{~S}\left(\mathrm{SiMe}_{3}\right)_{2} \underset{\left(\mathrm{H}_{2} \mathrm{O}\right)}{\stackrel{\mathrm{CH}_{2} \mathrm{Cl}_{2}}{\longrightarrow}}} \\
& {\left[\mathrm{Au}_{10} \mathrm{~S}_{2}\left(\mathrm{PPh}_{2}\right)_{2}(\mathrm{dppma} 2)_{4}(\mathrm{dppma} 3)\right]} \\
& \cdot \cdot\left[\mathrm{Au}_{6} \mathrm{~S}_{2}(\mathrm{dppma} 2)_{2}(\mathrm{dppma} 3)\right](\mathbf{1})+\left[\mathrm{Au}_{5}\left(\mathrm{PPh}_{2}\right)_{3}(\mathrm{dppma})_{2}\right] \\
& +\left[\mathrm{Au}_{24}\left(\mathrm{PPh}_{2}\right)_{4} \mathrm{~S}_{6}(\mathrm{dppma} 2)_{8}\right]
\end{aligned}
$$

Compound 1 possesses an overall near $C_{2}$ symmetry and is composed of two separate units, namely $\left[\mathrm{Au}_{10} \mathrm{~S}_{2}\left(\mathrm{PPh}_{2}\right)_{2}-\right.$ (dppma2 $\left.)_{4}(\mathrm{dppma3})\right]$ (1a) containing $\mathrm{Au}^{1+}, \mathrm{S}^{2-},\left(\mathrm{PPh}_{2}\right)^{-}$, and (dppma2)- ions, besides $\left[\mathrm{Au}_{6} \mathrm{~S}_{2}(\mathrm{dppma})_{2}(\mathrm{dppma})\right]$ (1b) con- 


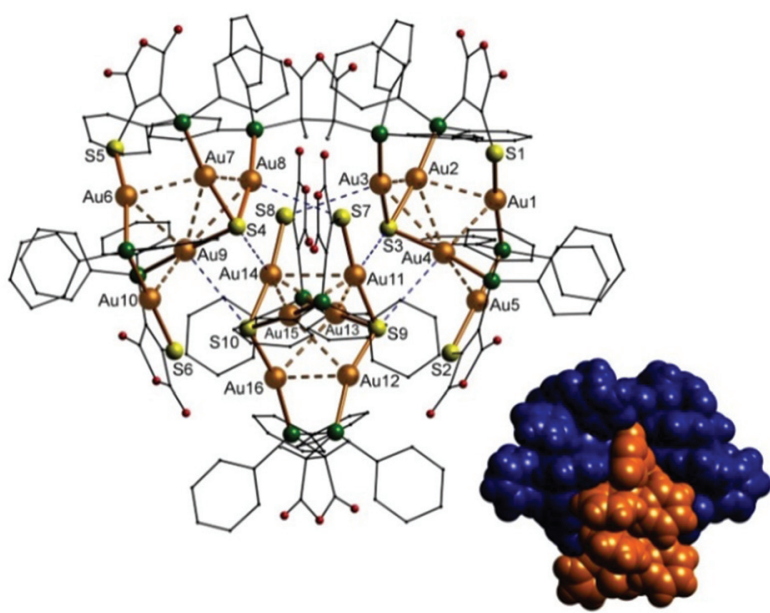

Fig. 1 Molecular structure of 1 in the crystal. The closest Au...Au dis-

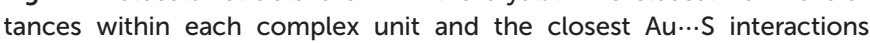
between $1 \mathrm{a}$ and $1 \mathrm{~b}$ are indicated by dashed golden or blue lines. For clarity, only $\mathrm{H}$ atoms of the central cycle of the dppma3 ligands are shown; Au: gold, S: yellow P: green, O: red, C: black, H: light grey; inset: the size-reduced space-filling model of 1 with $1 \mathrm{a}$ in blue and $1 \mathrm{~b}$ in gold.

taining $\mathrm{Au}^{1+}, \mathrm{S}^{2-}$, and $\left(\mathrm{PPh}_{2}\right)^{-}$ions, and neutral dppma3. It is worth noting that the two clusters that co-exist in $\mathbf{1}$ are neutral, which is rare and reminds of self-recognition of carbonyl clusters $;^{13}$ concerning gold sulfide cluster chemistry, it was observed for the first time and prompted us to undertake further investigations on their intermolecular interaction.

Furthermore, during the formation of complex 1 the initially reacted dppma ligand underwent various transformations that led to the generation of ligands dppma2 and dppma3, respectively. Replacement of a $\mathrm{PPh}_{2}$ fragment of dppma with a sulfide ligand yielded the negatively charged dppma2 ligand, thereby releasing a $\left(\mathrm{PPh}_{2}\right)^{-}$group to be involved in the formation of the cluster. In the other case, hydrogenation of the ring, presumably via intermediate silylation of the anhydride's enol form by $\mathrm{S}\left(\mathrm{SiMe}_{3}\right)_{2}$ and release of $\mathrm{Me}_{3} \mathrm{SiOH}$ in the presence of traces of water, led to the formation of the neutral ligand dppma3 (Scheme 1). The suggested route was indeed rationalized by detection of a mono-silylated intermediate acting as a ligand in $\left[\mathrm{Au}_{12}\left(\mathrm{PPh}_{2}\right)_{2} \mathrm{~S}_{4}(\mathrm{dppma} 4)_{4}\right]\left(\mathrm{BPh}_{4}\right)_{2} \cdot{ }^{12}$ These kinds of transformations have only been observed in the presence of $\operatorname{gold}(\mathrm{I})$, whereas analogous reactions with silver(I) or copper(I) do not yield any changes of the initial ligands. According to singlecrystal X-ray structure analyses, $\S \mathbf{1}$ (triclinic space group $P \overline{1}$, $Z=2$ ) crystallizes along with 14 molecules of dichloromethane per unit cell.

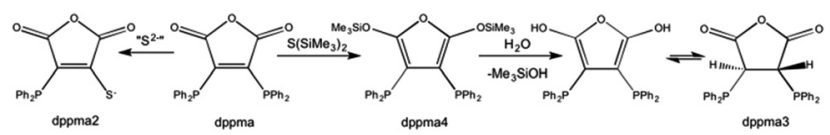

Scheme 1 Suggested derivatization of dppma yielding the ligands dppma2 and dppma3 alongside the synthesis of compound 1 .
The larger complex unit, $\left[\mathrm{Au}_{10} \mathrm{~S}_{2}\left(\mathrm{PPh}_{2}\right)_{2}(\mathrm{dppma} 2)_{4^{-}}\right.$ (dppma3)] (1a), has a horseshoe-like structure with two $\left\{\mathrm{Au}_{5}\right\}$ complex fragments linked together by a dppma3 ligand. Each of the $\left\{\mathrm{Au}_{5}\right\}$ fragments consists of a distorted $\left[\mathrm{Au}_{3} \mathrm{~S}\right]$ tetrahedron (Au2-Au4, S3 and $\mathrm{Au} 7-\mathrm{Au} 9, \mathrm{~S} 4)$ and an $\left[\mathrm{Au}-\left(\mathrm{PPh}_{2}\right)-\mathrm{Au}\right]$ unit (Au1, P2, Au5 and Au6, P7, Au10), which are linked by two dppma2 ligands. In the $\mu_{3}$-bridging $\left[\mathrm{Au}_{3} \mathrm{~S}\right]$ units the $\mathrm{Au}-\mathrm{S}-\mathrm{Au}$ angles range from $81.7(1)^{\circ}$ to $96.8(1)^{\circ}$, thus pretty close to the expected $90^{\circ}$ for essential 3p-bonding of sulfur atoms. The $\mathrm{Au}-\mathrm{S}$ and $\mathrm{Au}-\mathrm{P}$ bond lengths in 1a range from 230.5(3) pm to 233.9(3) pm and 225.3(3) to 229.0(3) pm, respectively. The $\mathrm{Au} \cdots \mathrm{Au}$ contacts of $1 \mathrm{a}$ are in the range of 289.1(1) pm and $340.3(1) \mathrm{pm}$.

The second complex unit, $\left[\mathrm{Au}_{6} \mathrm{~S}_{2}(\mathrm{dppma})_{2}(\mathrm{dppma} 3)\right](\mathbf{1 b})$, is hexanuclear, with a distorted cubane-like structure and the two sulfur atoms are at opposite apexes. Each sulfur atom coordinates to three gold(I) ions in a $\mu_{3}$-bridging mode, and the two $\left[\mathrm{Au}_{3} \mathrm{~S}\right]$ units are connected by two dppma2 ligands and one dppma3 ligand. The $\mathrm{Au} \cdots \mathrm{Au}$ distances range from 297.1(1) $\mathrm{pm}$ to 437.6(1) pm. The Au-S and $\mathrm{Au}-\mathrm{P}$ bond lengths in $\mathbf{1 b}$ range from 228.2(3) pm to 233.6(3) pm and 227.4(3) to 228.4(3) $\mathrm{pm}$, respectively, and the $\mathrm{Au}-\mathrm{S}-\mathrm{Au}$ angles are between $86.8(1)^{\circ}$ and 107.2(1) ${ }^{\circ}$; deviations from the ideal value of $90^{\circ}$ are often observed in gold(I) $\mu_{3}$-sulfido complexes. ${ }^{5-8,14}$

As shown in Fig. 1, 1a and $\mathbf{1 b}$ interdigitate, reminding of a lock-and-key like arrangement of both subunits. The shortest, yet non-bonding distances between $\mathbf{1 a}$ and $\mathbf{1 b}$ are $347 \mathrm{pm}$

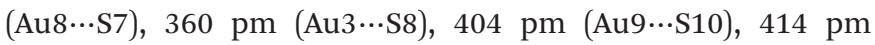

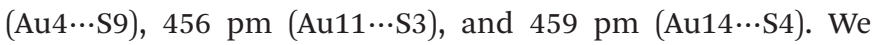
thus inferred that dipole-dipole interactions between the two complex units trigger the organization of the intriguing structure, which was further studied by means of quantum chemical investigations (vide infra). Very obviously, an opposite alignment of reverse polarizations is favored, as can be seen in the relative orientation of the Au3-S3-Au4 $\left(\delta^{+}-\delta^{-}-\delta^{+}\right)$and the S7-Au11-S9 $\left(\delta^{-}-\delta^{+}-\delta^{-}\right)$moieties, or the Au8-S4-Au9 $\left(\delta^{+}-\delta^{-}-\delta^{+}\right)$ and S8-Au14-S10 $\left(\delta^{-}-\delta^{+}-\delta^{-}\right)$moieties.

Quantum chemical calculations using the program system Turbomole V6. $5^{15}$ were undertaken to further explore the bonding within the complex, in particular to gain insight into the intramolecular $\mathrm{Au} \cdots \mathrm{Au}$ interactions ${ }^{16}$ and the intermolecular $\mathrm{Au} \cdots \mathrm{S}$ interactions. Density functional theory (DFT) methods $^{17-21}$ were used, employing Grimme's B97-D functional $^{22}$ (for further technical details, see below and the ESI†). Simultaneous optimization of the electronic and geometric structure was performed to rationalize the experimental results and to examine possible interactions within the two parts of the complex. For reduction of the computational effort, we symmetrized the complex to adopt $C_{2}$ symmetry, which is only barely missed in the crystal structure.

During the geometry optimization, all the Au-S bond lengths were constantly increased by $c a$. $4 \mathrm{pm}$ with respect to the experiment, as typical and expected for DFT calculations. The calculated Au-S bond lengths in $\mathbf{1 b}(230.8-237.5 \mathrm{pm})$ span a slightly wider range than the bond lengths in 1a (235.4-237.8 pm), in accordance with the experimental obser- 
vation. The calculated $\mathrm{S}-\mathrm{Au}-\mathrm{P}$ angles range from $164.6^{\circ}$ to $177.2^{\circ}$. The $\mathrm{S}-\mathrm{Au}-\mathrm{S}$ angles in $\mathbf{1 b}$ amount to $170.9^{\circ}$. Some angles show a clear deviation from the expected ideal linear coordination of the $\mathrm{Au}(\mathrm{I})$ atoms, both in the experiment and the calculations. The largest deviation calculated from experimental values for bond angles was observed for S3-Au3-P4 $\left(-5.5^{\circ}\right)$; all other values are in agreement with the experimentally found ones within less than $5^{\circ}$. All calculated and experimentally obtained values are listed in the ESI (Tables S1-S7 $\$$. Based on the good agreement of the experimental and calculated structures, we state that the chosen method is appropriate to model the compound and thus to comment on the bonding situation.

We therefore investigated the named short $\mathrm{Au} \cdots \mathrm{S}$ distances between the two subunits by inspection of canonical and localized molecular orbitals (MOs and LMOs). However, as illustrated in Fig. S1-S8, there is no indication of any bonding interaction between the quoted atoms even though the B97-D functional was used. Instead, we assume that a large number of short $\mathrm{S} \cdots \mathrm{H}$ and $\mathrm{O} \cdots \mathrm{H}$ distances are involved, as the respective lone pairs at the sulfide and oxide ligands clearly direct towards the hydrogen atoms. All distances are close to the sum of the van der Waals radii of hydrogen and oxygen or sulfur atoms, respectively (see Table S7 $\$$ ). Besides, the calculated $\mathrm{O} \cdot \mathrm{H}$ distances also correspond well to the normal range of $\mathrm{CH}$... O contact distances in organic crystal structures. ${ }^{23}$

As 1a and 1b do not represent an ion pair, the total interaction energy between the two subunits in $\mathbf{1}$ is based exclusively on dispersive interactions. It was possible to estimate this energy value by comparison of the total energy calculated for 1 with the sum of total energies calculated for the separated subunits in their original geometric structure. Scheme 2 illustrates the procedure that yielded $E_{\text {interaction }}=E_{\mathbf{1}}-\left[E_{\mathbf{1 a}}+\right.$ $\left.E_{\mathbf{1 b}}\right]=-649.5 \mathrm{~kJ} \mathrm{~mol}^{-1}$. Considering the twelve $\mathrm{S} \cdots \mathrm{H}$ and $\mathrm{O} \cdots \mathrm{H}$ interactions, this yields an interaction energy of $-54.1 \mathrm{~kJ}$ $\mathrm{mol}^{-1}$ per contact on average.

To examine possible aurophilic interactions within the subunits, shared electron numbers (SEN) were calculated via population analysis based on occupation numbers
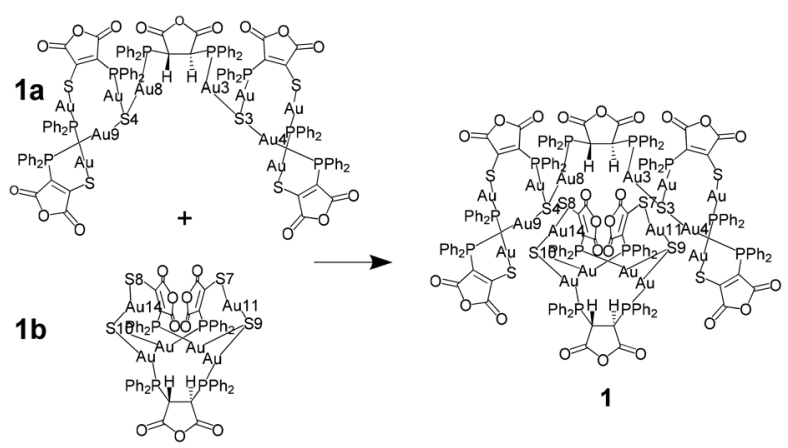

Scheme 2 Formal division of compound 1 into its two neutral subunits under specification of according total energies, summing up to $E=$ $-649.5 \mathrm{~kJ} \mathrm{~mol}^{-1}$.
(PABOON). ${ }^{24}$ The obtained values vary largely, from 0.09

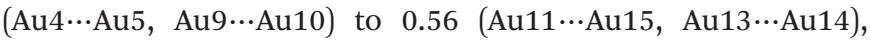
indicating some interaction at least for the contacts with the largest SEN. It should be noted that the observed $\mathrm{Au} \cdots \mathrm{Au}$ distances do not correlate in a strict way with the SEN values obtained (see Table S6 $\$$ ), both in $\mathbf{1 a}$ and $\mathbf{1 b}$. A possible explanation might be that the $\mathrm{Au}$ atoms are forced into these confirmations by the surrounding structures without actual bonding interactions.

In conclusion, we showed the successful preparation and characterization of a high-nuclearity gold(I) sulfido complex containing derivatives of bis(diphenylphosphino)maleic anhydride. The complex possesses a lock-and-key like structure as revealed by X-ray diffraction studies. According to DFT calculations, the two neutral subunits are held together mainly by $\mathrm{S} \cdots \mathrm{H}$ and $\mathrm{O} \cdots \mathrm{H}$ hydrogen bonds, reminiscent of the key interactions in bio-organic compounds, with a total interaction energy of about $-650 \mathrm{~kJ} \mathrm{~mol}^{-1}$.

\section{Notes and references}

$\S$ Crystal structure determination. Data collection at $150.15 \mathrm{~K}$ on a STOE StadiVari diffractometer with a Pilatus300 K detector using a Mo GeniX 3D HF micro focus X-ray source $(\lambda=0.71073 \AA)$. Structure solution by direct methods; fullmatrix least-squares refinement on $F^{2}$ using SHELX ${ }^{25}$ and OLEX2 ${ }^{26}$ software. $\mathrm{H}$ atoms added at idealized positions. Crystal Data for $\mathrm{C}_{191} \mathrm{H}_{156} \mathrm{Au}_{16} \mathrm{Cl}_{16} \mathrm{O}_{24} \mathrm{P}_{12} \mathrm{~S}_{10}$ ( $M 7246.05 \mathrm{~g} \mathrm{~mol}^{-1}$ ): triclinic, space group $P \overline{1}$ (no. 2), $a, b, c 15.4644(3), 25.0982(5)$, 27.0905(4) ̊, $\alpha, \beta, \gamma$ 92.194(1), 91.098(1), 93.130(1) ${ }^{\circ}, V 10488.8(3) \AA^{3}, Z 2$, $\mu(\mathrm{MoK} \alpha)=11.596 \mathrm{~mm}^{-1}, \rho_{\text {calc }}=2.294 \mathrm{~g} \mathrm{~cm}^{-3}, 79203$ refl. meas. $\left(3.01^{\circ} \leq 2 \Theta \leq\right.$ $\left.52.2^{\circ}\right), 40454$ unique $\left(R_{\mathrm{int}}=0.0653, R_{\sigma}=0.0644\right)$ used in all calculations. Final $R_{1} 0.0634(I>2 \sigma(I))$ and $\mathrm{w} R_{2} 0.1770$ (all data). CCDC 1046523. The low yield of 1 (ca. 5\%), its insolubility and the quoted co-crystallization hampered further analytical studies.

Quantum chemical methods. TURBOMOLE V6.5, ${ }^{15}$ RIDFT,${ }^{17}$ B97-D functional, ${ }^{22}$ (grid size m3), dispersion correction by DFT-D $3^{18}$ with BJ-damping, ${ }^{19}$ def2-TZVP basis sets, ${ }^{20}$ effective core potential (au def-ecp) ${ }^{21}$ at Au atoms. Mulliken, ${ }^{27}$ $\mathrm{NPA},{ }^{28}$ and PABOON ${ }^{24}$ analyses and Boys localization of MOs, ${ }^{29}$ as implemented in TURBOMOLE V6.5.

1 (a) M. C. Gimeno and A. Laguna, Chem. Soc. Rev., 2008, 37, 1952-1966; (b) M. Grzelczak, J. Perez-Juste, P. Mulvaney and L. M. Liz-Marzan, Chem. Soc. Rev., 2008, 37, 17831791; (c) G. J. Hutchings, M. Brust and H. Schmidbaur, Chem. Soc. Rev., 2008, 37, 1759-1765; (d) M. J. Katz, K. Sakai and D. B. Leznoff, Chem. Soc. Rev., 2008, 37, 18841895; (e) R. J. Puddephatt, Chem. Soc. Rev., 2008, 37, 20122027; $(f)$ H. G. Raubenheimer and S. Cronje, Chem. Soc. Rev., 2008, 37, 1998-2011; (g) G. Schmid, Chem. Soc. Rev., 2008, 37, 1909-1930; (h) V. W.-W. Yam and E. C. Cheng, Chem. Soc. Rev., 2008, 37, 1806-1813.

2 H. Schmidbaur and A. Schier, Chem. Soc. Rev., 2008, 37, 1931-1951.

3 (a) H. Schmidbaur, Gold Bull., 1990, 23, 11-21; H. Schmidbaur, Chem. Soc. Rev., 1995, 24, 391-400 (b) H. Schmidbaur, Gold Bull., 2000, 33, 3-10.

4 W. Yu, O. Fuhr and D. Fenske, J. Cluster Sci., 2012, 23, 753766. 
5 D. Fenske, T. Langetepe, M. M. Kappes, O. Hampe and P. Weis, Angew. Chem., Int. Ed., 2000, 39, 1857-1860.

6 P. Sevillano, O. Fuhr, O. Hampe, S. Lebedkin, C. Neiss, R. Ahlrichs, D. Fenske and M. M. Kappes, Eur. J. Inorg. Chem., 2007, 5163-5167.

7 F. K.-W. Hau, T. K.-M. Lee, E. C.-C. Cheng, V. K.-M. Au and V. W.-W. Yam, Proc. Natl. Acad. Sci. U. S. A., 2014, 111, 15900-15905.

8 E. C. C. Cheng, W. Y. Lo, T. K. M. Lee, N. Y. Zhu and V. W.W. Yam, Inorg. Chem., 2014, 53, 3854-3863.

9 (a) D. Fenske, Habilitation Thesis: Beiträge zur Chemie und Struktur neuer zweizähniger Phosphinliganden, 1977; (b) D. Fenske and H. J. Becher, Chem. Ber., 1975, 108, 21152123.

10 D. Fenske and H. J. Becher, Chem. Ber., 1974, 107, 117-122.

11 (a) H. J. Becher, W. Bensmann and D. Fenske, Chem. Ber./ Recl., 1977, 110, 315-321; (b) H. J. Becher, D. Fenske and M. Heymann, Z. Anorg. Allg. Chem., 1981, 475, 27-34; (c) D. Fenske, Chem. Ber., 1979, 112, 363-375.

12 W. Yu, PhD Thesis: Synthese und Charakterisierung von Münzmetall-Chalkogen-Komplexen mit 2,3-Bis(diphenylphosphino)maleinsäure -anhydrid und dessen Derivate als Liganden, Cuvillier Verlag Göttingen, 2014, p. 43ff.

13 (a) D. Braga, F. Grepioni, S. Righi, B. F. G. Johnson, P. Frediani, M. Bianchi, F. Piacenti and J. Lewis, Organometallics, 1992, 11, 706-711; (b) D. Braga and F. Grepioni, Organometallics, 1991, 10, 1254-1259.

14 (a) L.-Y. Yao, F. K.-W. Hau and V. W.-W. Yam, J. Am. Chem. Soc., 2014, 136, 10801-10806; (b) M. C. Gimeno and A. Laguna, Gold Bull., 2003, 36, 83-92.

15 TURBOMOLE V6.5 2013, a development of University of Karlsruhe and Forschungszentrum Karlsruhe GmbH, 1989-2007, TURBOMOLE GmbH, since 2007; available from http:// www.turbomole.com.
16 (a) S. Sculfort and P. Braunstein, Chem. Soc. Rev., 2011, 40, 2740-2760; (b) H. Schmidbaur and A. Schier, Chem. Soc. Rev., 2012, 41, 370-412.

17 (a) K. Eichkorn, O. Treutler, H. Öhm, M. Häser and R. Ahlrichs, Chem. Phys. Lett., 1995, 242, 652-660; (b) K. Eichkorn, F. Weigend, O. Treutler and R. Ahlrichs, Theor. Chim. Acta, 1997, 97, 119-124.

18 S. Grimme, J. Antony, S. Ehrlich and H. Krieg, J. Chem. Phys., 2010, 132, 154104.

19 S. Grimme, S. Ehrlich and L. Goerigk, J. Comput. Chem., 2011, 32, 1456-1465.

20 F. Weigend and R. Ahlrichs, Phys. Chem. Chem. Phys., 2005, 7, 3297-3305.

21 D. Andrae, U. Haeussermann, M. Dolg, H. Stoll and H. Preuss, Theor. Chim. Acta, 1990, 77, 123-141.

22 S. Grimme, J. Comput. Chem., 2006, 27, 17871799.

23 R. S. Scott and R. Taylor, J. Phys. Chem., 1996, 100, 73847391.

24 C. Ehrhardt and R. Ahlrichs, Theor. Chim. Acta, 1985, 68, 231-245.

25 G. Sheldrick, Acta Crystallogr., Sect. A: Fundam. Crystallogr., 2008, 64, 112-122.

26 O. V. Dolomanov, L. J. Bourhis, R. J. Gildea, J. A. K. Howard and H. Puschmann, OLEX2: A complete structure solution, refinement and analysis program, J. Appl. Crystallogr., 2009, 42, 339-341.

27 R. S. Mulliken, J. Chem. Phys., 1955, 23, 18331840.

28 A. E. Reed, R. B. Weinstock and F. Weinhold, J. Chem. Phys., 1985, 83, 735-746.

29 S. F. Boys, in Quantum Theory of Atoms, Molecules and the Solid State, ed. P.-O. Löwdin, Academic Press, New York, 1966, pp. 253-262. 